\title{
PCDD/PCDF and pl-PCBs Concentration in Ambient Atmosphere in the City of Tulkarm Using Passive Air Sampler
}

\author{
Nabil Shahin ${ }^{1}$, Amjad IA Hussein ${ }^{2,3}$, Jakob Reiman ${ }^{3}$, Suleiman AlKhalil ${ }^{2}$ \& Mazen Salman ${ }^{1}$ \\ ${ }^{1}$ College of Agricultural Science and Technology, Palestine Technical University- Kadoorie, Tulkarm, State of \\ Palestine \\ ${ }^{2}$ Medical Laboratory Sciences Department, Faculty of Medicine and Health Sciences, An-Najah National \\ University, Nablus, State of Palestine \\ ${ }^{3}$ Poison Control and Chemical-Biological Analysis Center, An-Najah National University, Nablus, State of \\ Palestine \\ Correspondence: Nabil Shahin, College of Agricultural Science and Technology, Palestine Technical University- \\ Kadoorie, Tulkarm, State of Palestine. E-mail: nabilshahin@hotmail.de
}

Received: June 22, 2017

doi:10.5539/ep.v6n2p34
Accepted: July 12, $2017 \quad$ Online Published: September 29, 2017

URL: https://doi.org/10.5539/ep.v6n2p34

\begin{abstract}
This study investigates the presence of highly toxic and carcinogenic compounds such as dioxins, furans and dioxin-like polychlorinated biphenyls, which may have evolved as a result of many industrial and burning processes, in Tulkarm ambient atmosphere. The measured concentrations were compared to values found in other studies undertaken in other sites globally. PCB 118, PCB 104 and PCB 77 were the main congeners making the ambient air profile of Tulkarm city, Palestine. While PCDFs were detected in about $40 \%$ of air samples no PCDDs were recorded. The contribution of Gishori complex area to air pollution was considered.
\end{abstract}

Keywords: PCDDs, PCDFs, air pollution, passive air sampler

\section{Introduction}

Polychlorinated dibenzo-p-dioxins (PCDDs) and polychlorinated dibenzofurans (PCDFs) (Fig. 1) are two series of planar, tricyclic ethers, which have up to eight chlorine atoms attached to carbon (Morrison \& Murphy, 2006).

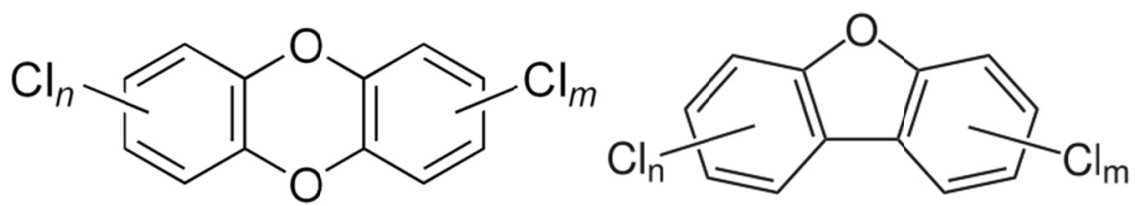

Figure 1. Chemical structures of PCDDs (left) and PCDFs (right)

PCDDs and PCDFs are known to be some of the most toxic persistent organic pollutants (POPs) in the environment. They can cause cancer and have negative effects on the human reproductive and immune systems (Kogevinas, 2001; Biegel \& Safe, 1990). The main source of human exposure to dioxin is through diet, mainly meat, fish, and dairy products (Travis \& Hattemer-Frey, 1991). Dioxins accumulate in the fatty tissues, where they may persist for months or years (Fierens et al., 2003). PCDDs and PCDFs can be formed through many industrial processes such as chlorine bleaching of pulp (Hrutfiord \& Negri, 1992), medical and municipal waste incineration (Liem, Hoogerbrugge, Kootstra, van der Velde \& de Jong, 1991) and many other processes such as cement kilns, municipal wastewater treatment, sludge and secondary copper smelting (U.S. EPA, 2006). Moreover, dioxins can be formed from various combustion sources like burning treated wood, combustion of leaded gasoline in automobiles and firing of coal. Dioxin-like poly chlorinated biphenyls (PCBs) congeners (Fig. 2), have a co-planar structure very similar to that of dioxins and have dioxin-like effects (Ahlborg et al., 1994). They have been intentionally produced by humans for different purposes such as an insulating material in electrical equipment, surface coatings, inks, adhesives and flame-retardants (Fernandes et al., 2008). Similar to 
dioxins, PCBs can accumulate in the food chain, especially in oils and fats (Olanca, Cakirogullari, Ucar, Kirisik, \& Kilic, 2014).

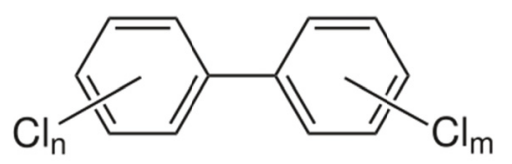

Figure 2. Chemical structures of PCBs

In general, there are a few studies about air pollution and air quality in the West Bank, Palestine. The scarcity of data on air pollutant emissions in the Palestinian Territories refers to the hardly adequate measurement infrastructure. Since there is no power generation or heavy industry in the West Bank, air quality has not been viewed as an important issue in comparison to other environmental domains such as those mentioned by Color et al. (2011). The city of Tulkarm, which borders the Geshori industrial complex, had its environmental profile analyzed in 1996 by the Applied Research Institute-Jerusalem (ARIJ) (ARIJ, 1996) and Alkhalil and Qasem (2009). The air pollution in this region was superficially discussed, focusing on sulphur, nitrogen and carbon oxides, which may come from transportation, industry and energy production emissions in Israel (ARIJ, 1996).

PCDDs, PCDFs and dl-PCBs, as possible air pollutants, were mentioned in just a few studies concerning burning solid waste dumpsites in some cities in Palestine (El-Hamouz, 2002). To the authors knowledge no study has been undertaken to analyze PCDD/ PCDFs or PCBs in air samples in any city in West Bank. The aim of this study was to investigate the presence of dioxins, furans and dioxin-like polychlorinated biphenyls in the Tulkarm ambient atmosphere.

\section{Method}

A pre-cleaned PUF foam disk with a density of $0.0213 \mathrm{~g} \cdot \mathrm{cm}^{-3}$, a diameter of $14 \mathrm{~cm}$ and a thickness of $1.35 \mathrm{~cm}$ was used as the passive air sampler. It was deployed in a sheltered chamber consisting of two steel bowls, as shown in Figure (3), to protect the foam disks from direct precipitation, sunlight and coarse particle deposition.

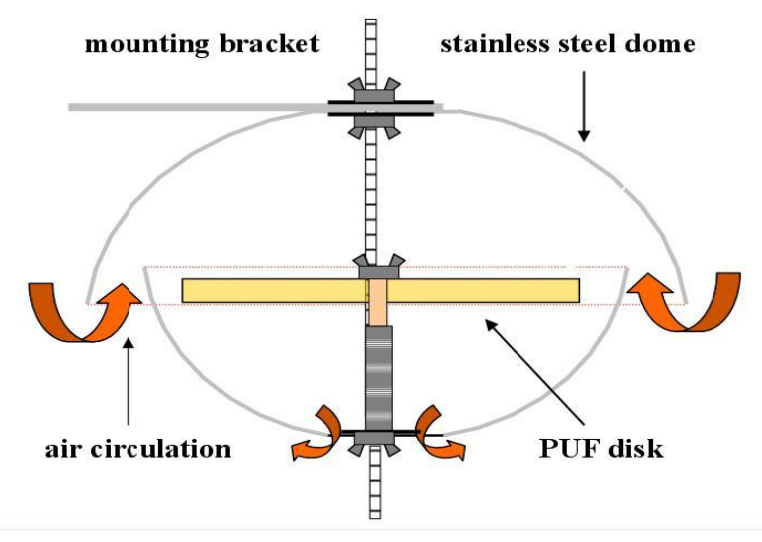

Figure 3. Schematic representation of sampler housing

In order to determine the dioxins and dioxin-like compounds in ambient air in Tulkarm city, seven air samples in different locations were collected in one sampling campaign between the end of July and the end of August 2015 Table (1) and Figure (4) show the sampling locations. 
Table 1. Detailed locations sampling sites according to coordinates

\begin{tabular}{lll}
\hline Location & Latitude & Distance in Meter \\
\hline 1 & $32^{\circ} 18^{\prime} 14.11^{\prime \prime} \mathrm{N} 35^{\circ} 0^{\prime} 54.99^{\prime \prime} \mathrm{E}$ & 49 \\
2 & $32^{\circ} 18^{\prime} 24.00^{\prime \prime} \mathrm{N} 35^{\circ} 0^{\prime} 58.70^{\prime \prime} \mathrm{E}$ & 125 \\
3 & $32^{\circ} 18^{\prime} 11.25^{\prime \prime} \mathrm{N} 35^{\circ} 1^{\prime} 16.00^{\prime \prime} \mathrm{E}$ & 590 \\
4 & $32^{\circ} 17^{\prime} 54.10^{\prime \prime} \mathrm{N} 35^{\circ} 1^{\prime} 10.70^{\prime \prime} \mathrm{E}$ & 774 \\
5 & $32^{\circ} 18^{\prime} 37.10^{\prime \prime} \mathrm{N} 35^{\circ} 1^{\prime} 26.00^{\prime \prime} \mathrm{E}$ & 934 \\
6 & $32^{\circ} 18^{\prime} 56.71^{\prime \prime} \mathrm{N} 35^{\circ} 66^{\prime} 31.09^{\prime \prime} \mathrm{E}$ & 8876 \\
7 & $32^{\circ} 13^{\prime} 37.53^{\prime \prime} \mathrm{N} 35^{\circ} 17^{\prime} 42.57^{\prime \prime} \mathrm{E}$ & 27837 \\
\hline
\end{tabular}
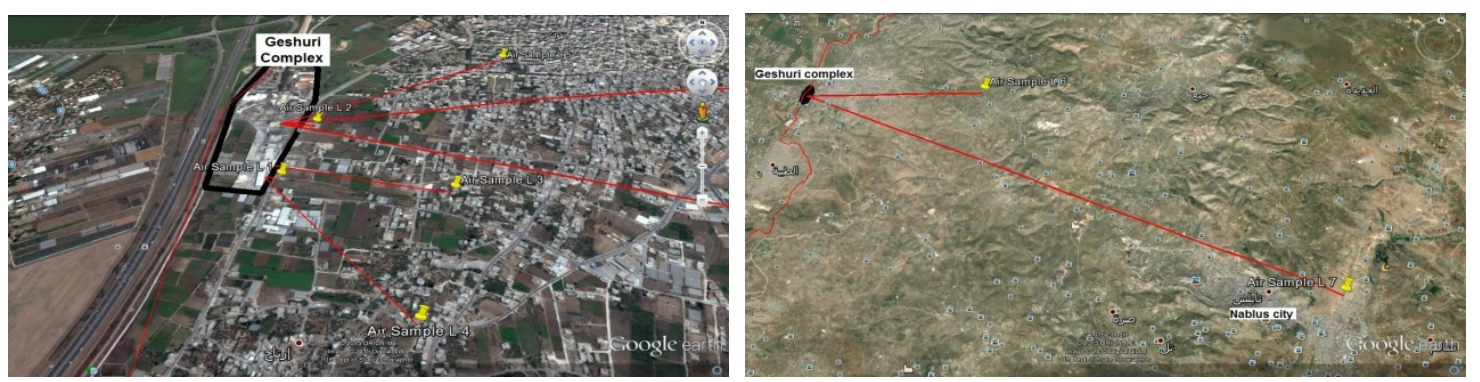

Figure 4. Position of expected polluted sampling sites: sample 1,2,3,4 and 5 (left)) and control sites: sample 6 and 7 (right)

After a sampling time of 4 weeks, the PUF disks were collected and each was wrapped carefully with aluminium foil and sent to Eurofins laboratories in Hamburg, Germany, to analyze the target compounds. For quality assurance, a wrapped PUF disk with aluminium and plastic foil was used as a blank sample and set in location 1 with sample 1 . To compare the ambient atmosphere quality in Tulkarm city especially around the industrial zone, two air samples (sample 6 and 7) were taken at a greater distance from the studied area.

\section{Results and Discussion}

In this study, according to the literature (Wilford, Harner, Zhu, Shoeb, \& Johnes, 2004; Moussaoui, Tuduri, Kerchich, Meklati, \& Eppe, 2012), we used $3.5 \mathrm{~m}^{3} \mathrm{~d}^{-1}$ as a sampling rate for the passive PUF sampler and applied it to all studied substances collected in the 28 days campaign. No PCDD/PCDFs and dl-PCBs concentrations were detected above the limit of quantification (LOQ) in the blank sample, though there were traces which may indicate that the contamination resulted from transportation, storage or analysis.

Table 2 and figure 5 show the PCDD/PCDDFs and dl-PCBs concentrations of seven samples located at different distances from Gishori industrial area. Taking the concentration of PCDDs traces in the blank sample into consideration by subtracting them from those in the samples, we find that all samples in the different locations might be considered free of PCDDs. However, three samples contained PCDFs, with concentrations slightly above the LOQ. Subtracting the half values of LOQ found in the blank sample, $0.045 \mathrm{pg} \cdot \mathrm{m}^{-3}$ of $1,2,3,4,6,7$, 8 -HeptaCDF and $0.02 \mathrm{pg} \cdot \mathrm{m}^{-3}$ of 2, 3, 7, 8-TetraCDF in sample 2 and 3 respectively. Sample 4 contained four congeners of PCDFs: 2, 3, 7, 8-TetraCDF, 1, 2, 3, 7 , 8-PentaCDF, 2, 3, 4, 7, 8-PentaCDF and 1, 2, 3, 4, 6, 7, 8 -HeptaCDF, their concentrations are $0.037,0.023,0.043$ and $0.033 \mathrm{pg} \cdot \mathrm{m}^{-3}$, respectively. Although this sample was located at about 800 meters to the east north of Gishori, for some reason, it contained a sum of toxic equivalent of $0.015 \mathrm{pg}$ TEQ $\cdot \mathrm{m}^{-3}$ which is significantly higher than those of samples 2 and $3(0.00004$ and 0.0019 pg TEQ $\cdot \mathrm{m}^{-3}$ ) which were sampled close to the industrial area. Compared to other international values, our study showed that in Tulkarm city concentrations are less than the range in five sites measured in Belgium $(0.02-0.59$ pg TEQ $\left.\mathrm{m}^{-3}\right)$, urban Germany $\left(0.07-0.35 \mathrm{pg}\right.$ TEQ $\left.\mathrm{m}^{-3}\right)$ and 4 sites in Sydney, Australia, $(0.02-0.06 \mathrm{pg}$ TEQ $\mathrm{m}^{-3}$ ). These values were located within the range from 0.014 to $0.024 \mathrm{TEQ} \cdot \mathrm{m}^{-3}$ in urban and suburban sites in Sweden and higher than the estimated value in the air from the North Sea in the Netherlands $(0.005 \mathrm{pg}$ TEQ $\left.\cdot \mathrm{m}^{-3}\right)$ and a coastal site in Sweden $\left(0.003-0.004 \mathrm{pg}\right.$ TEQ $\cdot \mathrm{m}^{-3}$ ) (Air quality Guideline, 2000). 
Table 2. Concentrations $\left(\mathrm{pg} \cdot \mathrm{m}^{-3}\right)$ of PCDD/PCDFs and dl-PCBs in different samples

\begin{tabular}{|c|c|c|c|c|c|c|c|c|}
\hline \multirow[t]{2}{*}{ Compound } & \multicolumn{8}{|c|}{ Sample } \\
\hline & blank & 1 & 2 & 3 & 4 & 5 & 6 & 7 \\
\hline 2,3,7,8-TetraCDD & $<0.02$ & $<0.02$ & $<0.02$ & $<0.02$ & $<0.02$ & $<0.02$ & $<0.02$ & $<0.02$ \\
\hline 1,2,3,7,8-PentaCDD & $<0.02$ & $<0.02$ & $<0.02$ & $<0.02$ & $<0.02$ & $<0.02$ & $<0.02$ & $<0.02$ \\
\hline 1,2,3,4,7,8-HexaCDD & $<0.05$ & $<0.05$ & $<0.05$ & $<0.05$ & $<0.05$ & $<0.05$ & $<0.05$ & $<0.05$ \\
\hline 1,2,3,6,7,8-HexaCDD & $<0.05$ & $<0.05$ & $<0.05$ & $<0.05$ & $<0.05$ & $<0.05$ & $<0.05$ & $<0.05$ \\
\hline 1,2,3,7,8,9-HexaCDD & $<0.05$ & $<0.05$ & $<0.05$ & $<0.05$ & $<0.05$ & $<0.05$ & $<0.05$ & $<0.05$ \\
\hline $1,2,3,4,6,7,8$-HeptaCDD & $<0.06$ & $<0.06$ & $<0.06$ & $<0.06$ & $<0.06$ & $<0.06$ & $<0.06$ & $<0.06$ \\
\hline OctaCDD & $<0.22$ & $<0.22$ & $<0.22$ & $<0.22$ & $<0.22$ & $<0.22$ & $<0.22$ & $<0.22$ \\
\hline 2,3,7,8-TetraCDF & $<0.03$ & $<0.03$ & $<0.03$ & 0.035 & 0.05 & $<0.03$ & $<0.03$ & $<0.03$ \\
\hline $1,2,3,7,8$-PentaCDF & $<0.04$ & $<0.04$ & $<0.04$ & $<0.04$ & 0.05 & $<0.04$ & $<0.04$ & $<0.04$ \\
\hline 2,3,4,7,8-Penta CDF & $<0.04$ & $<0.04$ & $<0.04$ & $<0.04$ & 0.06 & $<0.04$ & $<0.04$ & $<0.04$ \\
\hline $1,2,3,4,7,8-\mathrm{HexaCDF}$ & $<0.04$ & $<0.04$ & $<0.04$ & $<0.04$ & $<0.04$ & $<0.04$ & $<0.04$ & $<0.04$ \\
\hline $1,2,3,6,7,8-\mathrm{HexaCDF}$ & $<0.04$ & $<0.04$ & $<0.04$ & $<0.04$ & $<0.04$ & $<0.04$ & $<0.04$ & $<0.04$ \\
\hline $1,2,3,7,8,9-\mathrm{HexaCDF}$ & $<0.04$ & $<0.04$ & $<0.04$ & $<0.04$ & $<0.04$ & $<0.04$ & $<0.04$ & $<0.04$ \\
\hline 2,3,4,6,7,8-HexaCDF & $<0.04$ & $<0.04$ & $<0.04$ & $<0.04$ & $<0.04$ & $<0.04$ & $<0.04$ & $<0.04$ \\
\hline 1,2,3,4,6,7,8-HeptaCDF & $<0.05$ & $<0.05$ & 0.07 & $<0.05$ & 0.06 & $<0.05$ & $<0.05$ & $<0.05$ \\
\hline 1,2,3,4,7,8,9-HeptaCDF & $<0.04$ & $<0.04$ & $<0.04$ & $<0.04$ & $<0.04$ & $<0.04$ & $<0.04$ & $<0.04$ \\
\hline OctaCDF & $<0.3$ & $<0.3$ & $<0.3$ & $<0.3$ & $<0.3$ & $<0.3$ & $<0.3$ & $<0.3$ \\
\hline PCB 77 & $<0.37$ & 0.80 & 1.07 & 0.95 & 1.00 & 0.81 & 1.03 & 1.28 \\
\hline РCB 81 & $<0.08$ & $<0.08$ & 0.11 & 0.12 & 0.12 & $<0.08$ & $<0.08$ & $<0.08$ \\
\hline PCB 105 & $<0.8$ & 1.90 & 2.35 & 2.05 & 2.28 & 2.29 & 2.62 & 2.96 \\
\hline PCB 114 & $<0.10$ & 0.15 & 0.20 & 0.20 & 0.22 & 0.16 & 0.24 & 0.22 \\
\hline PCB 118 & $<2.86$ & 4.38 & 5.29 & 4.92 & 6.20 & 6.18 & 7.13 & 7.31 \\
\hline PCB 123 & $<0.08$ & $<0.08$ & 0.09 & 0.09 & 0.13 & 0.10 & 0.11 & 0.11 \\
\hline PCB 126 & $<0.10$ & $<0.10$ & 0.14 & 0.13 & 0.14 & $<0.10$ & 0.14 & 0.13 \\
\hline PCB 156 & $<0.45$ & $<0.45$ & $<0.45$ & $<0.45$ & $<0.45$ & $<0.45$ & $<0.45$ & $<0.45$ \\
\hline PCB 157 & $<0.09$ & $<0.09$ & $<0.09$ & $<0.09$ & 0.11 & $<0.09$ & 0.11 & $<0.09$ \\
\hline PCB 167 & $<0.22$ & $<0.22$ & $<0.22$ & $<0.22$ & $<0.22$ & $<0.22$ & $<0.22$ & $<0.22$ \\
\hline PCB 169 & $<0.24$ & $<0.24$ & $<0.24$ & $<0.24$ & $<0.24$ & $<0.24$ & $<0.24$ & $<0.24$ \\
\hline PCB 189 & $<0.08$ & $<0.08$ & $<0.08$ & $<0.08$ & $<0.08$ & $<0.08$ & $<0.08$ & $<0.08$ \\
\hline
\end{tabular}

$<$ concentration means $<$ concentration below the indicated limit of quantification provided by Eurofins laboratories, Hamburg, Germany. 


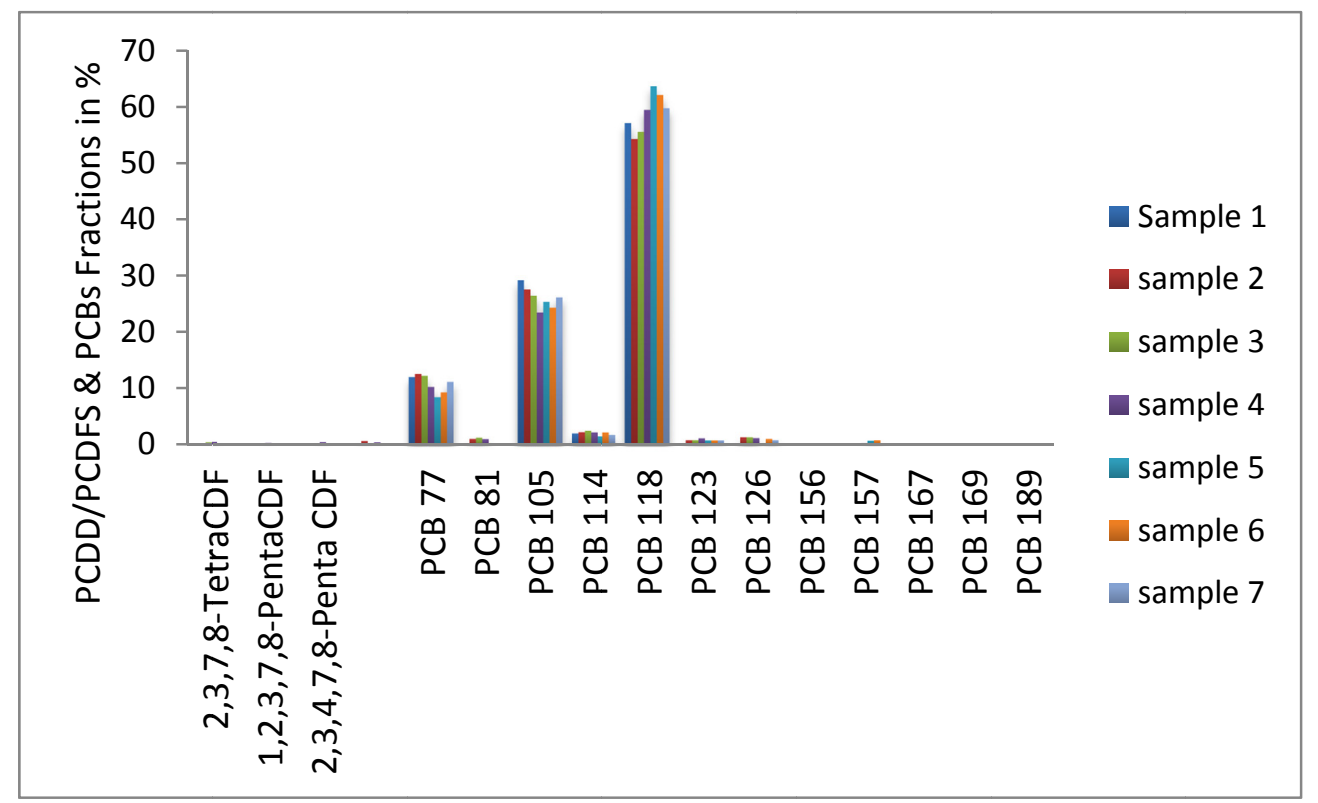

Figure 5. PCDD/PCDFs and dl-PCBs fractions in samples located at different distances from Gishori.

Regardless of the distance of the samples to Gishori, all samples have the same dl-PCBs profile and almost the same fractions. All profiles are dominated by PCB 118 (57 - 64 \%) followed by PCB104 (23 - 29\%) and then by PCB $77(8-11 \%)$.

As shown in Table 3, there is no relation between the location of the samples from the industrial area and the total (PCDD/PCDDFs + dl-PCBs). However, the concentration range of these compounds, in the Tulkarm area, is much smaller than, for example, northern Algeria $\left(0.249-0.771 \Sigma(\mathrm{PCDD} / \mathrm{Fs}+\mathrm{dl}-\mathrm{PCBs}) \mathrm{pg} \mathrm{TEQ} \cdot \mathrm{m}^{-3}\right)$ (Moussaoui et al, 2012).

Table 3. Total concentration of PCDD/PCDFs and dl-PCBs, in terms of WHO 2005-TEQ, of samples located at different distances from the north east of Gishori.

\begin{tabular}{lll}
\hline & $\begin{array}{l}\text { samples location } \\
\text { Gishori in meter }\end{array}$ & $\begin{array}{l}\text { to } \\
{[\mathrm{PCDD} / \mathrm{Fs}+\mathrm{dl}-\mathrm{PCBs})} \\
{\left[\mathrm{pg} \mathrm{TEQ} \cdot \mathrm{m}^{-3}\right]}\end{array}$ \\
\hline Sample 1 & 49 & 0.0002 \\
Sample 2 & 125 & 0.01 \\
Sample 3 & 590 & 0.0103 \\
Sample 4 & 770 & 0.0244 \\
Sample 5 & 934 & 0.0003 \\
Sample 6 & 88876 & 0.0093 \\
Sample 7 & 27837 & 0.008 \\
\hline
\end{tabular}

\section{Conclusions}

Within the 28 days sampling campaign, no serious dioxin, furans or dioxin-like poly chlorinated biphenyls pollution were found in the ambient atmosphere of Tulkarm city. The values of toxic equivalency of these compounds in the city were found to be much lower than many comparative sites in the world. Since the sampling campaign was too short, it would therefore be advisable to extend the sampling campaign for one year to control the air quality during such time. Moreover, due to the high toxicity of dioxin, furan and dioxin-like poly chlorinated biphenyls and the existence of the industrial area in Tulkarm, a permanent monitoring of these compounds in the ambient air of the city is highly recommended. 


\section{Acknowledgments}

This work was supported by the Belgian fund to the Palestinian Authority under Ref, C3, Contract PZA282 EQA, 2015. The project contractor was Expoworks Plus Company in favor of the Palestine Environment Quality Authority (EQA)

\section{References}

Ahlborg, U. G., Becking, G. C., Birnbaum, L. S., Brouwer, A. H., Derks, J. G. M., Feeley, M., \& Yrjäinheikki, E. (1994). Toxic equivalency factors for dioxin-like PCBs. Chemosphere, 28(6), 1049-1067. https://doi.org/10.1007/bf02986503

Air Quality Guideline-2nd Edition. (2000). Copenhagen, Denmark, WHO Regional Office for Europe. Retrieved from http://www.euro.who.int/_data/assets/pdf_file/0017/123065/AQG2ndEd_5_11PCDDPCDF.pdf

Alkhalil, S., \& Qasem, I. (2009). The impact of Israeli Industrial Zone on Environmental and Human Health in Tulkarm City. Proceedings, 2nd International Conference on the Palestinian Environment, An-Najah National University, Nablus Palestine, 196-208.

Applied Research Institute- Jerusalem (ARIJ). (1996). Environmental Profile for the West Bank Volume 8: District Tulkarm. Retrieved from http://www.arij.org/files/admin/1996 5_Environmantal_Profiles_for_the_West_Bank_Volume_8_Tulkarem_District.pdfhttp://www.arij.org/files/ admin/19965_Environmantal_Profiles_for_the_West_Bank_Volume_- 8 - Tulkarem_District.pdf

Biegel, L., \& Safe, S. (1990). Effects of 2,3,7,8-tetrachlorodibenzo-p-dioxin (TCDD) on cell growth and the secretion of the estrogen-induced 34-, 52- and 160-kDa proteins in human breast cancer cells. The Journal of Steroid Biochemistry and Molecular Biology, 37, (5), 725-32. https://doi.org/10.1016/0960-0760(90)90357-q

Color, G., Hanberg, A., Larsen, J. C., Liem, A. K. D., Safe, S. H., Schlatter, C., ... Bar-On Atrash, H. I. (2011). Analysis for European Neighbourhood Policy (ENP) Countries and the Russian Federation of social and economic benefits of enhanced environmental protection - occupied Palestinian territory Country Report. Retrieved from http://www.ecologic.eu/sites/files/publication/2015/opt-enpi_benefit_assessment_0.pdf

El-Hamouz, A. M. (2002). Medical Waste Incineration in Nablus City, West Bank: Case Study. The Arabian Journal for Science and Engineering, 27, 29-40.

Fernandes, A., Dicks, P., Mortimer, D., Gem, M., Smith, F., Driffield, M., White, S., \& Rose, M. (2008). Brominated and chlorinated dioxins, PCBs and brominated flame retardants in Scottish shellfish: Methodology, occurrence and human dietary exposure. Molecular Nutrition \& Food Research, 52(2), 238249. https://doi.org/10.1002/mnfr.200700135

Fierens, S., Mairesse, H., Hermans, C., Bernard, A., Eppe, G., Focant, J. F., \& Pauw, E. (2003). Dioxin accumulation in residents around incinerators. Journal of Toxicology and Environmental Health, 66(17), 1287-1293. https://doi.org/10.1080/15287390306391

Hrutfiord, B. F., \& Negri, A. R. (1992). Dioxin Sources and mechanisms during pulp bleaching. Chemosphere, 25(1-2), 53-56. https://doi.org/10.1016/0045-6535(92)90478-a

Huang, H., \& Buekens, A. (1995). On the mechanisms of dioxin formation in combustion processes. Chemosphere, 31(9), 4099-4117. https://doi.org/10.1016/0045-6535(95)80011-9

Kogevinas, M. (2001). Human health effects of dioxin: cancer, reproductive and endocrine system. Hum Reprod Update, 7(3), 331-339. https://doi.org/10.1111/j.1600-0463.2001.tb05771.x

Liem, A. K. D., Hoogerbrugge, R., Kootstra, P. R., van der Velde, E. G., \& de Jong, A. P. J. M. (1991). Occurrence of dioxins in cow's milk in the vicinity of municipal waste incinerators and a metal reclamation plant in the Netherlands. Chemosphere, 23(11), 1675-1684. https://doi.org/10.1016/0045-6535(91)90016-7

Morrison, R. D., \& Murphy, B. L. (2006). Environmental Forensics - Contaminant Specific Guide. Burlington, MA: Elsevier Inc.

Moussaoui, Y., Tuduri, L., Kerchich, Y., Meklati, B. Y., \& Eppe, G. (2012). Atmospheric concentrations of PCDDIFs, dl-PCBS and some pesticides in northern Algeria using air sampling. Chemosphere, 88, 270-277. https://doi.org/10.1016/j.chemosphere.2012.02.025

Olanca, B., Cakirogullari, C. G., Ucar, Y., Kirisik, D., \& Kilic, D. (2014). Polychlorinated dioxins, furans $(\mathrm{PCDD} / \mathrm{Fs})$, dioxin-like polychlorinated biphenyls (dl-PCBs) and indicator PCBs (ind-PCBs) in egg and 
egg products in Turkey. Chemosphere, 94, 13-19. https://doi.org/10.1016/j.chemosphere.2013.08.056

Travis, C. C., \& Hattemer-Frey, H. A. (1991). Human exposure to dioxin. Sci. Total Environ, 104(1), 97-127.

U.S. Environmental Protection Agency (EPA). (2006). An inventory of sources and environmental releases of dioxin-like compounds in the United States for the years 1987, 1995, and 2000. National Center for Environmental Assessment, Washington, DC: EPA/600/P-03/002F. Retrieved from http://www.epa.gov/ncea/pdfs/dioxin/2006/dioxin.pdf

Wilford, B. H., Harner, T., Zhu, J. P., Shoeb, M., \& Johnes, K. C. (2004). Passive sampling survey of polybrominated diphenyl ether flame retardants in indoor and outdoor air in Ottawa, Canada: implications for sources and exposure. Environmental Science \& Technology, 38, 5312-5318. https://doi.org/10.1021/es049260x

\section{Copyrights}

Copyright for this article is retained by the author(s), with first publication rights granted to the journal.

This is an open-access article distributed under the terms and conditions of the Creative Commons Attribution license (http://creativecommons.org/licenses/by/4.0/). 